\title{
Research on Project Teaching Method of Vehicle Dynamics under the Background of "New Engineering"
}

\author{
Sha Xu, Hui Guo, Huanhuan Zhang, Xintian Liu \\ Shanghai University of Engineering Science, Shanghai, China \\ Email: xytongxing376@sina.com
}

How to cite this paper: $\mathrm{Xu}, \mathrm{S}$., Guo, H., Zhang, H.H. and Liu, X.T. (2021) Research on Project Teaching Method of Vehicle Dynamics under the Background of "New Engineering". Open Access Library Journal, 8: e7157.

https://doi.org/10.4236/oalib.1107157

Received: January 18, 2021

Accepted: February 22, 2021

Published: February 25, 2021

Copyright $\odot 2021$ by author(s) and Open Access Library Inc.

This work is licensed under the Creative Commons Attribution International License (CC BY 4.0).

http://creativecommons.org/licenses/by/4.0/

\begin{abstract}
Vehicle Dynamics is a compulsory course of vehicle engineering. At present, the teaching method is still dominated by teachers. There are some problems, such as insufficient engineering oriented teaching content, unable to mobilize students' learning enthusiasm and so on, which cannot meet the training needs of "New Engineering" for engineers. Based on the concept of project teaching, this paper discusses the teaching content and teaching mode of Vehicle Dynamics, so as to improve students' participation in the course and improve the teaching quality of the course.
\end{abstract}

\section{Subject Areas}

Mechanical Engineering

Keywords

New Engineering, Vehicle Dynamics, Project Teaching, Teaching Content

\section{Introduction}

Vehicle Dynamics is a compulsory course of vehicle engineering. This course is widely offered in the major of vehicle engineering in Chinese universities. The main task of the course is to learn the basic laws of automobile motion and force, the main technical performance indexes and their theoretical calculation, the corresponding evaluation and test methods, as well as the structures and factors affecting these performances. Through the study of the course, students can understand the methods and ways to design cars correctly and use cars reasonably. The Vehicle Dynamics course lays the necessary professional theoretical knowledge for the subsequent Automobile Design, Graduation Design and other 
courses, and lays the necessary theoretical foundation for students to engage in automobile-related in the future.

At present, the global manufacturing industry has fully entered a new era of transformation. As the concentrated embodiment of the manufacturing industry, the automobile industry will be the first to be affected by this round of changes [1]. With the rapid development of the automobile manufacturing industry, the requirements for training automotive engineering talents are getting higher and higher. In order to cultivate new engineering talents, the Ministry of Education of China has proposed the construction of "New Engineering", which aims to further improve engineering students' engineering application ability, practical ability, innovation ability and international competitiveness [2]. The existing course content of Vehicle Dynamics is mainly based on the traditional internal combustion engine vehicle. At present, new energy vehicles and automatic driving vehicles are becoming mainstream products. The original course content can not fully cover the development of existing technology, and cannot meet the requirements of "New Engineering" for talent training. Moreover, due to the limitation of class hours, confirmatory experiments are often used in teaching, which is often difficult to meet the needs of cultivating students' engineering practice ability.

In the face of the new situation of great changes in the automotive industry and the new requirements of "New Engineering" for talent training, many universities have conducted research and reforms on the teaching methods of automotive-related professional courses, and have achieved certain results. In these studies, project-based teaching has been favored by more and more universities [3] [4] [5] [6].

This paper first summarizes the problems existing in the current Vehicle Dynamics teaching. Then, in view of these problems, the paper puts forward the project teaching method of Vehicle Dynamics. On the basis of the existing teaching content, the project-based teaching content is formulated, the project-based teaching mode is discussed, and finally the assessment method of project teaching is given.

\section{The Main Problems Existing in the Course}

At present, there are several problems in the teaching of Vehicle Dynamics.

1) Teaching emphasizes theory rather than practice and lacks the explanation of cutting-edge technologies and emerging technologies

Using the traditional classroom teaching mode, the content of the teaching materials is still mainly fuel vehicles. This course introduces the performance of automobile, such as dynamic performance, fuel economy performance, braking performance, handling stability performance, ride comfort performance, trafficability and evaluation indicators of these performance. In the process of teaching, we pay more attention to the systematicness, logic and completeness of knowledge of basic theories. This will easily cause the current teaching content of Vehicle Dynamics to be not closely related to the development of the automo- 
tive industry and the needs of engineering practice. Under the current rapid development of new energy vehicles and smart vehicles, the teaching of Vehicle Dynamics lacks the explanation of cutting-edge technologies and emerging technologies. The teaching obviously lags behind the rapid development of the automobile industry, which is not conducive to students' mastery of new formats and new technologies.

2) Traditional teaching methods cannot stimulate students' interest and initiative

Based on mechanics, Vehicle Dynamics integrates the basic principles and methods of many courses, such as Automobile Structure and Theoretical Mechanics. It is complex, comprehensive and abstract. In the classroom teaching process, some students reported that the course was difficult and boring. The traditional teaching method is mainly based on the teacher's explanation, with a large number of formula derivation and analysis. Students only passively accept the teacher's explanation in class, and the classroom participation is relatively low.

3) Experimental teaching emphasizes verification

In the current experimental teaching, due to the limitation of the class time and experimental site, the experiments are mainly to verify the contents of the theoretical teaching in the classroom. Students just use the existing equipments to complete the specified experiments according to the contents of the experiment guide book, and lack exploratory practice. This experimental teaching method is not conducive to cultivating students' ability to discover, analyze, and solve problems, and it is also difficult to cultivate high-skilled, innovative, and application-oriented engineering talents under the background of "New Engineering".

\section{Contents of Project Teaching}

Project teaching method originated from work-study education in Europe and cooperative education in the United States. It refers to teaching activities carried out by teachers and students to implement a complete project together. Project teaching method combines classroom teaching with practical engineering problems. According to the degree of difficulty and logical relationship, the teaching content is divided into several projects. Based on these projects, teachers guide and supervise students to complete each teaching project. In project teaching, the teacher is the instructor and the students are the implementers. It is a teaching organization method that takes students as the main body, takes ability training as the core, and combines theory and practice. Through the implementation of the projects, students can build a new knowledge system on the basis of the original knowledge, enhance their interest and initiative, so as to improve their practical ability, autonomous learning ability, post ability, application ability and team cooperation ability.

Project teaching is consistent with the demand for engineering talents under the background of "New Engineering". On the basis of teaching materials [7], 
the whole course of Vehicle Dynamics is divided into six projects, which are automobile dynamics, fuel economy, automobile braking, automobile handling stability, automobile ride comfort and automobile trafficability. In each project, multiple tasks are formulated according to learning objectives and ability requirements [8] [9], as shown in Figure 1. In the project-based teaching content, it is necessary to set up the relevant task content according to the students' ability training, which conforms to the students' cognitive level, combines the difficulty with the ease, and set up some expansion projects for the students who are willing to learn more.

\section{Project Teaching Mode}

In teaching, project tasks are set according to the needs of ability training. Each project task can be freely grouped by classmates, with 4 to 5 people in each general group. Taking the dynamic performance as an example, the teacher first clarifies the task name, task requirements, and the results that should be obtained, and gives the students corresponding guidance in theoretical knowledge, answers students' questions, and coordinates the internal work of students. The students are free to form a group to work together, draw up a discussion plan and finally implement the plan to complete each task. The specific task design is shown in Table 1. After the task is completed, each group submitted the driving force-running resistance diagram and acceleration curve drawn by hand and computer programming. In the process of completing the task, it can cultivate students' ability to discover, put forward and solve problems, enhance students' ability of independent thinking and sense of teamwork, and mobilize students' initiative. Students can better grasp the basic concepts, principles and methods of the six performances of automobile, be familiar with the development trend and academic frontier of automobile industry, cultivate students' innovative thinking ability, broaden their knowledge, and lay a solid foundation for their graduation and employment.

\section{Assessment Method}

In order to scientifically, reasonably and comprehensively evaluate students' course learning conditions, a process-based assessment method is introduced [10]. Examination and evaluation will run through the learning process of the entire course, rather than just a final exam. As shown in Table 2, the assessment mainly consists of four parts: project participation, project report, project results display and closed-book examination.

The closed-book examination can accurately test the students' memory and understanding of the professional knowledge of the course, but it is difficult to reflect the students' ability to solve practical problems. The process assessment method can more objectively and accurately reflect the students' comprehensive ability from different perspectives. Process assessment accounts for $60 \%$ of the evaluation methods, which can make teachers pay attention to the reaction state 
of students in the learning process and find out the problems in the teaching process in time. In the early stage of project teaching, through the assessment of students' participation in problem discussion and project division, students' subjective initiative can be improved and their learning enthusiasm can be stimulated. In the process of project implementation, it can improve students' ability to find, analyze and solve problems, and enhance students' sense of teamwork. Finally, through the project summary and defense, improve students' communication ability on a specific project.

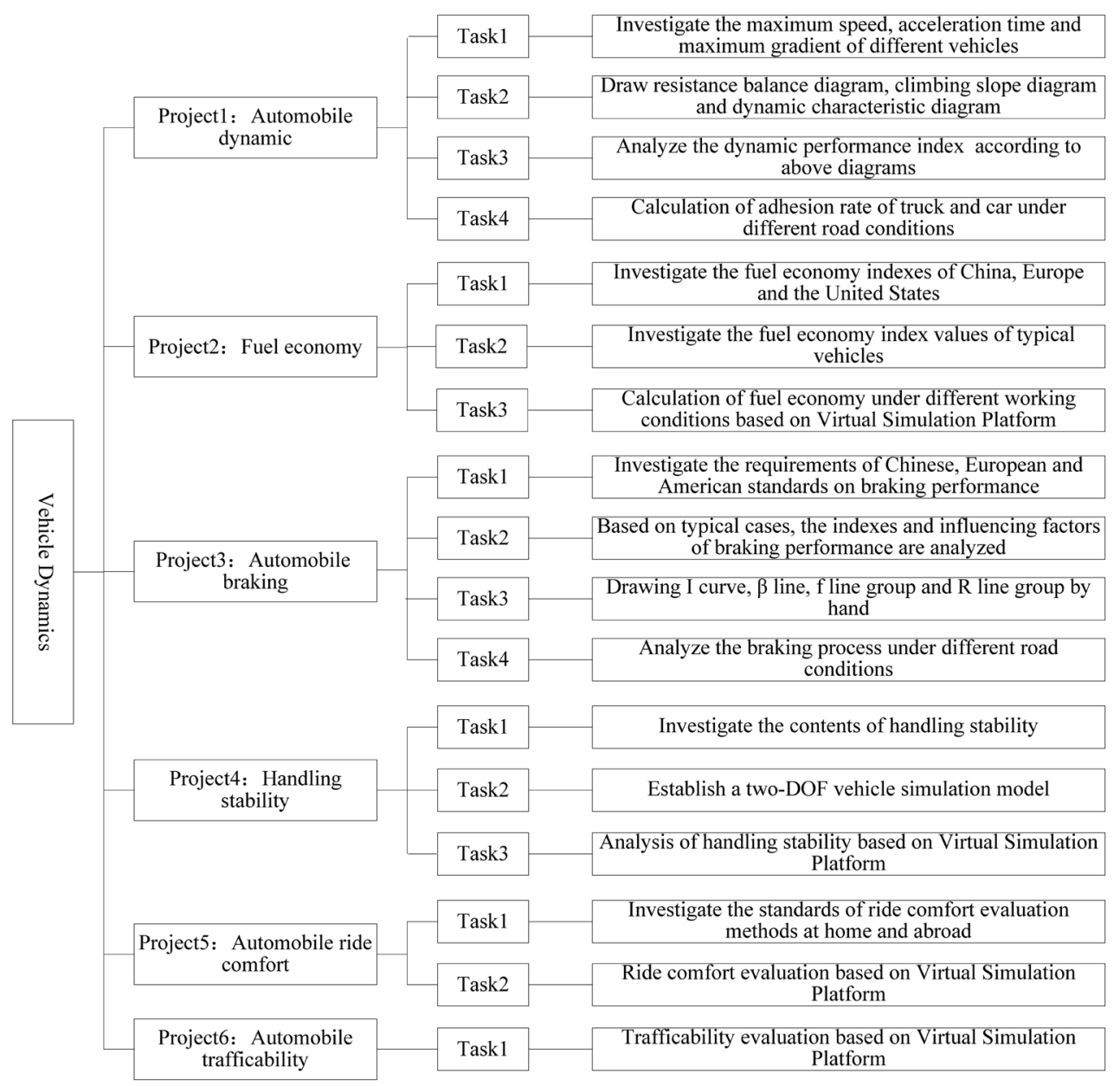

Figure 1. Project teaching contents of Vehicle Dynamics.

Table 1. Task design of automobile dynamic.

\begin{tabular}{|c|c|c|c|c|c|}
\hline Project & Task & Basic Knowledge & Teaching objectives & implementation & Results \\
\hline $\begin{array}{l}\text { Project 1: } \\
\text { Automobile } \\
\text { Dynamic }\end{array}$ & $\begin{array}{l}\text { Task 2: Draw the driving } \\
\text { force-running resistance } \\
\text { balance diagram and } \\
\text { acceleration curve of a } \\
\text { given car by manual and } \\
\text { Matlab programming } \\
\text { methods. }\end{array}$ & $\begin{array}{l}\text { Driving equation, } \\
\text { driving force } \\
\text { calculation, relationship } \\
\text { between vehicle speed } \\
\text { and engine speed }\end{array}$ & $\begin{array}{l}\text { Use mechanics, } \\
\text { diagrams, and } \\
\text { computer software } \\
\text { to solve practical } \\
\text { problems }\end{array}$ & $\begin{array}{l}\text { Collect and search the relevant } \\
\text { information, make the } \\
\text { calculation plan; Group discussion } \\
\text { and modification plan; Team } \\
\text { members work together to draw } \\
\text { graphics in different ways; Sorting } \\
\text { out the data and analyzing the } \\
\text { influencing factors; }\end{array}$ & $\begin{array}{l}\text { Report on drawing } \\
\text { driving } \\
\text { force-running } \\
\text { resistance balance } \\
\text { diagram }\end{array}$ \\
\hline
\end{tabular}


Table 2. Assessment method.

\begin{tabular}{|c|c|c|c|c|}
\hline Stage & Assessment & Item & Score & Detailed description \\
\hline \multirow{5}{*}{$\begin{array}{l}\text { Process } \\
\text { assessment }\end{array}$} & \multirow{2}{*}{ Project participation } & Project discussion & 10 & Participate in discussions and answer questions \\
\hline & & Participation & 10 & Project task division and workload \\
\hline & \multirow{2}{*}{ Project report } & Project plan & 10 & Task description, grouping, planning, solution, knowledge application \\
\hline & & Report & 20 & Project implementation steps, project summary, problems and thinking \\
\hline & $\begin{array}{l}\text { Project results } \\
\text { display }\end{array}$ & Project defense & 10 & $\begin{array}{l}\text { The beauty of PPT, whether the theme is clear, and the understanding of } \\
\text { the problem }\end{array}$ \\
\hline Final exam & $\begin{array}{l}\text { closed-book } \\
\text { examination }\end{array}$ & Final exam & 40 & $\begin{array}{l}\text { Each knowledge point of the teaching content specified in the } \\
\text { assessment outline }\end{array}$ \\
\hline
\end{tabular}

\section{Conclusions}

"New engineering" points out the direction for the training of vehicle engineering professionals. Professional courses are the main way to achieve ability training, and the teaching quality of professional courses directly determines the achievement of training goals. As an important professional compulsory course of vehicle engineering, the project teaching content of Vehicle Dynamics directly affects the teaching quality of the course, which plays an important role in students' follow-up course learning and graduation design. Therefore, the project-based teaching of Vehicle Dynamics also needs to summarize experience in continuous practice, improve the project content design, and further meet the demand of "new engineering" for vehicle engineering talents.

Based on the traditional Vehicle Dynamics teaching material, this paper formulates the project teaching contents and tasks. The project teaching mode is explored, which changes the traditional teaching method based on classroom lectures. The assessment method based on process is adopted. Through the project teaching method, students' interest and initiative in learning are improved, and the cultivation of students' comprehensive ability is enhanced.

Although the project teaching method can produce a good teaching effect, there are still some shortcomings in the actual teaching.

First of all, how to define the division of roles between teachers and students in project practice is still a problem. When students participate in practical projects, on the one hand, if teachers supervise too little, the quality of the project cannot be guaranteed; on the other hand, if teachers supervise too much, students' ability cannot be improved.

Secondly, not all chapters of the course are suitable for project-based teaching. For example, in the chapter of automobile dynamic, the theoretical knowledge is too much and too complex for students to master by themselves. At this time, it is better to still use the traditional classroom teaching method.

\section{Acknowledgements}

This work was supported by the Teaching Construction Project of Shanghai University of Engineering Science No. x202001004. 


\section{Conflicts of Interest}

The authors declare no conflicts of interest regarding the publication of this paper.

\section{References}

[1] Zhao, F.Q., Liu, Z.W., Hao, H. and Shi, T.Z. (2018) Characteristics, Trends and Opportunities in Changing Automotive Industry. Journal of Automotive Safety and Energy, 9, 233-249.

[2] Liu, H.T., Xu, Q.Y. and Xiao, Q. (2019) Research and Practice of Vehicle Engineering Specialty Construction and Personnel Training from the Perspective of New Engineering. China Modern Educational Equipment, No. 327, 101-103.

[3] Zhang, P. (2019) Research on the Project-Based Reconstruction of Secondary Vocational Curriculum for the Cultivation of Computational Thinking. Shaanxi Normal University, Xi'an.

[4] Zhang, B.B. (2019) Research on Application of Project Based Learning in University Teaching-Based on the Theory of Process Philosophy. Central China Normal University, Wuhan.

[5] Hou, J.M., Wang, M.L., Yang, Q.L. and Liu, S.Q. (2019) The Explore of Project-Teaching Reformation Based on CDIO: With CAD/CAM Comprehensive Training as an Example. China Modern Educational Equipment, No. 313, 66-68.

[6] Ma, Y.J., Jiang, X.Y. and Fan, X.Y. (2019) Reform and Exploration of Project Practical Teaching System Based on Emerging Engineering Education. Education Modernization, No. 36, 83-85.

[7] Yu, Z.S. (2018) Automobile Theory. China Machine Press, Beijing.

[8] Lu, L.Q. (2013) Reform and Practice of Automobile Theory Course Driven by Project. University Education, No. 16, 86-87.

[9] Xiao, Y. (2017) Application of Project Driven Teaching Mode in Automobile Theory Teaching. Western China Quality Education, No. 10, 75-76.

[10] Liu, C. (2020) Research and Practice on the Reform of the Assessment Mode of Project Teaching Package Based on OBE Mode. The Guide of Science \& Education, No. 4, 66-68. 